\title{
PENGEMBANGAN E-MODUL BERBASIS MODEL PEMBELAJARAN PROJECT BASED LEARNING PADA MATA PELAJARAN PEMROGRAMAN GRAFIK KELAS XII REKAYASA PERANGKAT LUNAK DI SMK NEGERI 2 TABANAN
}

\author{
Kadek Dwi Suantara ${ }^{1}$, I Gede Mahendra Darmawiguna ${ }^{2}$, Nyoman Sugihartini ${ }^{3}$ \\ Program Studi Pendidikan Teknik Informatika \\ Jurusan Teknik Informatika \\ Fakultas Teknik dan Kejuruan \\ Universitas Pendidikan Ganesha \\ email: dedex.bogel87@gmail.com ${ }^{1}$, mahendra.darmawiguna@undiksha.ac.id ${ }^{2}$, sugihartini@undiksha.ac.id ${ }^{3}$
}

\begin{abstract}
Abstrak - Penelitian ini bertujuan (1) Untuk mengimplementasikan Pengembangan E-modul Pada Mata Pelajaran Pemrograman Grafik Kelas XII Rekayasa Perangkat Lunak di SMK Negeri 2 Tabanan. (2) Untuk mengetahui respon siswa dan guru terhadap Pengembangan E-modul Pada Mata Pelajaran Pemrograman Grafik Kelas XII dengan Model Project Based Learning di SMK Negeri 2 Tabanan. Metode penelitian yang digunakan dalam penelitian ini adalah research and development ( $\mathrm{R} \& \mathrm{D})$, dengan model pengembangan ADDIE. Subjek penelitian ini yaitu siswa kelas XII Rekayasa Perangkat Lunak dan guru mata pelajaran Pemrograman Grafik di SMK Negeri 2 Tabanan tahun ajaran 2018/2019. Untuk mengetahui respon siswa dan guru terhadap e-modul diperoleh dengan menggunakan metode angket. Hasil penelitian menunjukkan bahwa: 1) Hasil implementasi e-modul yang telah dikembangkan pada mata pelajaran pemrograman grafik untuk siswa kelas XII Rekayasa Perangkat Lunak dengan menggunakan model pembelajaran Project Based Learning di SMK Negeri 2 Tabanan dinyatakan berhasil diterapkan berdasarkan beberapa uji yang dilakukan. 2) Hasil analisis data respon siswa menunjukkan bahwa persentase siswa yang memberikan respon sangat baik sebesar $36.84 \%$, persentase siswa yang memberikan respon baik sebesar $63.16 \%$, dan tidak ada siswa yang memberikan respon cukup, kurang, maupun sangat kurang dan mendapatkan presentase tingkat pencapaian e-modul sebesar $87.58 \%$. Sedangkan hasil analisis data respon guru menunjukkan bahwa persentase guru yang memberikan respon sangat baik sebesar $94 \%$.
\end{abstract}

Kata kunci: E-modul, Pemrograman Grafik, Model Project Based Learning, Research and Development

\footnotetext{
Abstract - The aim of this study is to (1) Implement the development of E-module for Graphic Progamming learning lesson of grade XII with Project Based Learning Model in SMK Negeri 2 Tabanan. (2) To know students, and teachers' response towards the development of $E$ -
}

module for Graphic Progamming learning lesson of grade XII with Project Based Learning Model in SMK Negeri 2 Tabanan. Research methodology that is used for this research was Research and Development $(R \& D)$, with ADDIE (Analysis, Design, Development or production, Implementation or delivery and Evaluation) development model. The subject of this research was the third grade students, engineer software and Graphic Progamming teachers of SMK Negeri 2 Tabanan in Academic Year 2018/2019. To know students' and teachers' response towards the E-module was gained by using inquiry method. The result of this study showed that: (1) Implementation result of E-module which was developed for Grafik Progamming learning lesson of grade XII engineer software by using Project Based Learning Model in SMK Negeri 2 Tabanan has proven effective to be applied through some tests. (2) The data analysis result of students' response showed that the percentage of students' who give excellent response was $36.84 \%$, students who gave good response were $63.16 \%$, and there were no students who gave fair response, inadequate or inacceptable response and get a percentage of the level of achievement of the e-module were $87.58 \%$. While the data analysis result of teachers' response showed that the percentage of teaches who gave excellent response was $94 \%$.

Keywords: E-Module, Grafik Progamming, project based learning, Research and Development

\section{PENDAHULUAN}

Setiap manusia berhak mendapatkan pendidikan yang layak untuk mengubah kehidupannya. Hal ini sesuai dengan [1] yakni "Setiap warga negara berhak mendapat pendidikan". Pendidikan merupakan usaha sadar dan terencana untuk mewujudkan suasana belajar dan proses pembelajaran agar peserta didik secara aktif mengembangkan potensi dirinya untuk memiliki kekuatan spiritual keagamaan, pengendalian diri, kecerdasan, akhlak mulia, serta keterampilan yang diperlukan dirinya, 
ISSN 2252 - 9063

Kumpulan Artikel Mahasiswa Pendidikan Teknik Informatika

(KARMAPATI)

\section{KคRMดPดTI}

măsyarăkat, bangsa dan negara tentang Sistem Pendidikan Nasional). Tujuan pendidikan nasional seperti dinyatakan pada [2] Tentang Sistem Pendidikan Nasional adalah mengembangan kemampuan dan membentuk watak serta peradaban bangsa yang bermatabat dalam rangka mencerdaskan kehidupan bangsa, bertujuan untuk berkembangnya potensi peserta didik agar menjadi manusia beriman dan bertakwa kepada Tuhan Yang Maha Esa, berakhlak mulia, sehat, berilmu, cakap, kreatif, mandiri, dan menjadi warga Negara yang demokratis serta bertanggung jawab. Pengembangan potensi peserta didik memiliki kajian yang sangat luas, terutama masalah yang terkait dengan kualitas pendidikan di Indonesia saat ini.

Proses pembelajaran akan berjalan dengan baik apabila didukung oleh tersedianya sumber belajar belajar, media pembelajaran dan model pembelajaran yang tepat. Salah satu upaya untuk peningkatan proses pembelajaran adalah penggunaan media secara efektif mempertinggi kualitas yang akhirnya dapat meningkatkan kualitas hasil belajar [3]. Media pembelajaran dan model pembelajaran adalah sarana untuk membantu peserta didik dan guru dalam menempuh proses belajar-mengajar di dalam kelas. Penggunaan media dan model pembelajaran yang tepat dapat mempengaruhi suatu proses pembelajaran di kelas, media pembelajaran yang lengkap dan terstruktur akan mempermudahkan siswa dalam melakukan proses pembelajaran serta penggunaan model pembelajaran yang tepat akan membuat proses pembelajaran berjalan baik.

Berdasarkan observasi yang peneliti lakukan di SMKN 2 Tabanan terhadap proses pembelajaran serta pengisian angket dengan guru pengampu mata pelajaran pemrograman grafik dan siswa jurusan rekayasa perangkat lunak kelas XII pada tanggal 16 Februari 2017, dapat diketahui bahwa terdapat beberapa permasalahan yaitu :

1. Guru sebagai pengajar masih banyak yang menggunakan metode dan media konvensional dalam mengajarkan materi pengajaran.

2. Pembelajaran yang dilakukan oleh guru masih bersumber kepada internet karena sekolah tidak lagi menyediakan buku cetak. Sumber belajar yang di dapat dari internet tidak terstruktur dan lengkap.

3. Belum pernah adanya e-modul yang digunakan di SMK Negeri 2 Tabanan sehingga guru lebih sulit saat memberikan materi dan selalu membuat slide sebelum melaksanakan pertemuan.

4. Siswa belum sepenuhnya tertarik mengikuti proses pembelajaran dan cepat merasa bosan dikarenakan penyajian pembelajaran menggunakan media konvensional.

Pemrograman grafik pada Kurikulum 2013 tergolong mata pelajaran baru sehingga membuat materi pelajaran menjadi terlalu luas menyebabkan siswa kurang tertarik mencari materi di internet, hal ini mendasari perlunya adanya suatu bahan ajar yang lengkap dan terstruktur tentang materi pemrograman grafik. Berdasarkan hasil penyebaran angket, $88 \%$ koresponden menyatakan pentingnya suatu wadah untuk mengakses materi yang sudah tersusun lengkap. Selain itu permasalahan lain yang
Volume 8, Nomor 2, Tahun 2019

seperti harga buku atau bahan ajar cetak yang menghabiskan biaya yang cukup mahal, serta materi yang sering dicari siswa pada internet sering berbeda pemahaman karena berasal dari sumber yang berbeda. Berdasarkan permasalahan diatas maka peneliti mengambil pemrograman grafik sebagai mata pelajaran yang akan dibuatkan media pembelajaran berupa modul elektronik.

Menurut [4] fungsi model pembelajaran adalah sebagai pedoman bagi perancang pengajar dan para guru dalam melaksanakan pembelajaran. Project Based Learning merupakan pembelajaran inovatif yang berpusat pada siswa (student centered) dan menempatkan guru sebagai motivator dan fasilitator, dimana siswa diberi peluang bekerja secara otonom mengkonstruksi belajarnya. Berdasarkan uraian di atas, maka tujuan utama dari penelitian ini adalah mengembangkan sebuah EModul Berbasis Model Pembelajaran Project Based Learning pada Mata Pelajaran Pemrograman Grafik Kelas XII Rekayasa Perangkat Lunak di SMK Negeri 2 Tabanan. Pengembangan ini diharapkan dapat membantu proses pembelajaran siswa guna untuk meningkatkan hasil belajar siswa di sekolah.

\section{KAJIAN TEORI}

\section{Mata Pelajaran Pemrograman Grafik}

Menurut [5] mengemukakan bahwa pemrograman grafik adalah programming paradigm yang menggunakan obyek dan interaksinya untuk merancang aplikasi dan program komputer. Pemrograman grafik merupakan salah satu mata pelajaran produktif program keahlian rekayasa perangkat lunak di SMK Negeri 2 Tabanan. Tujuan dalam mempelajari pemrograman grafik adalah pemahaman dasar untuk siswa sekaligus sebagai pengenalan awal mengenai bahasa pemrograman. Selain untuk merancang sebuah aplikasi tujuan pemrograman grafik adalah merancang dan mendesain sebuah tampilan aplikasi sehingga dapat terlihat menarik.

Materi pemrograman grafik yang terdapat pada silabus mata pelaran pemrograman grafik keahlian rekayasa perangkat lunak di SMK Negeri 2 Tabanan tersusun selama 1 semester (semester ganjil). Pada materi silabus dijabarkan materi pemrograman grafik dari awal pengenalan aplikasi pendukung, pembuatan sebuah program atau aplikasi, merancang visualisasi atau interface program hingga pembuatan installer dan dokumentasi aplikasi. Berikut akan dijelaskan mengenai kompetensi dasar serta materi pokok yang terdapat pada silabus yang akan digunakan dalam pengembangan emodul pemrograman grafik.

\section{Model Pembelajaran Berbasis Proyek}

Menurut [6] mengemukakan model pembelajaran adalah sebuah kerangka konseptual yang digunakan sebagai pedoman dalam melakukan pembelajaran. Dengan demikian, model pembelajaran merupakan kerangka konseptual yang melukiskan prosedur yang sistematis dalam mengorganisasikan pengalaman belajar untuk mencapai tujuan belajar. Jadi model pembelajaran 
KARMAPATI

cenđeruntry presteriptif, yang relatif sulit dibedakan dengan strategi pembelajaran.

Menurut [7] mengungkapkan bahwa project-Based Learning berisi 6 fase utama yang dimulai dengan orientasi masalah yang disampaikan guru untuk mengarahkan siswa tentang situasi masalah dan membentuk kelompok, melakukan investigasi, merencanakan laporan, presentasi laporan, dan evaluasi seperti yang dapat dilihat pada Tabel 1.

TABEL 1 SINTAKS MODEL PROJECT BASED LEARNING [7]

\begin{tabular}{|c|c|c|}
\hline Tahap & Aktivitas Guru & Aktivitas Siswa \\
\hline $\begin{array}{l}\text { Tahap-1 } \\
\text { (eksplorasi) } \\
\text { Orientasi masalah }\end{array}$ & $\begin{array}{l}\text { Menyampaikan tema } \\
\text { sesuai dengan } \\
\text { kompetensi inti }\end{array}$ & $\begin{array}{l}\text { Mengamati atau } \\
\text { menganalisa suatu } \\
\text { permasalahan yang } \\
\text { diberikan, } \\
\text { mengikuti petunjuk } \\
\text { guru. }\end{array}$ \\
\hline $\begin{array}{l}\text { Tahap-2 } \\
\text { 1. Membentuk } \\
\text { kelompok } \\
\text { 2. Merencanakan } \\
\text { kegiatan } \\
\text { kelompok }\end{array}$ & $\begin{array}{l}\text { 1. Mengintruksikan } \\
\text { siswa untuk } \\
\text { membentuk } \\
\text { kelompok (3-4 } \\
\text { orang) } \\
\text { 2. Membimbing } \\
\text { siswa } \\
\text { mempersiapkan } \\
\text { investigasi } \\
\text { a. Pemilihan } \\
\text { topic } \\
\text { b. Membuat peta } \\
\text { konsep atau } \\
\text { diagram } \\
\text { c. Membuat } \\
\text { rincian } \\
\text { terhadap } \\
\text { tahapan proses } \\
\text { d. Monitoring } \\
\text { kerja proyek }\end{array}$ & $\begin{array}{l}\text { 1. Membentuk } \\
\text { kelompok (3-4 } \\
\text { orang), } \\
\text { mengikuti } \\
\text { petunjuk guru. } \\
\text { 2. } \text { Merencanakan } \\
\text { kegiatan } \\
\text { investigasi } \\
\text { a. } \quad \text { Pemilihan } \\
\text { topic } \\
\text { b. } \\
\text { Membuat } \\
\text { peta konsep } \\
\text { atau diagram } \\
\text { c. } \text { Membuat } \\
\text { rincian } \\
\text { terhadap } \\
\text { tahapan } \\
\text { proses } \\
\text { d. } \text { Monitoring } \\
\text { kerja proyek }\end{array}$ \\
\hline $\begin{array}{l}\text { Tahap-3 } \\
\text { (elaborasi) } \\
\text { Melakukan } \\
\text { investigasi }\end{array}$ & $\begin{array}{l}\text { Membimbing siswa } \\
\text { melakukan investigasi }\end{array}$ & $\begin{array}{l}\text { Melakukan } \\
\text { investigasi }\end{array}$ \\
\hline $\begin{array}{l}\text { Tahap-4 } \\
\text { Merencanakan } \\
\text { laporan }\end{array}$ & $\begin{array}{l}\text { Membimbing dan } \\
\text { mengarahkan } \\
\text { penyusunan laporan }\end{array}$ & $\begin{array}{l}\text { Menyusun laporan } \\
\text { hasil investigasi }\end{array}$ \\
\hline $\begin{array}{l}\text { Tahap-5 } \\
\text { (konfirmasi) } \\
\text { Presentasi laporan }\end{array}$ & $\begin{array}{l}\text { Memgasilitasi kegiatan } \\
\text { presentasi laporan } \\
\text { proyek dan berperan } \\
\text { sebagai narasumber }\end{array}$ & $\begin{array}{l}\text { Mempresentasikan } \\
\text { laporan kegiatan } \\
\text { proyek }\end{array}$ \\
\hline $\begin{array}{l}\text { Tahap-6 } \\
\text { evaluasi }\end{array}$ & $\begin{array}{l}\text { Melakukan evaluasi } \\
\text { terhadap laporan hasil } \\
\text { proyek }\end{array}$ & $\begin{array}{l}\text { Mendokumentasikan } \\
\text { masukan-masukan } \\
\text { guru yang } \\
\text { berhubungan dengan } \\
\text { proyek }\end{array}$ \\
\hline
\end{tabular}

3. Modul Ajar

Modul pembelajaran merupakan satuan program belajar mengajar yang terkecil, yang dipelajari oleh siswa sendiri secara perseorangan atau diajarkan oleh siswa kepada dirinya sendiri (self-instructional) [8].Strategi pengoperasian materi pembelajaran mengandung squencing yang mengacu pada pembuatan urutan penyajian materi pelajaran, dan synthesizing yang mengacu pada upaya untuk menunjukkan kepada pembelajaran keterkaitan antara fakta, konsep, prosedur
Volume 8, Nomor 2, Tahun 2019

dan prinsip yang terkandung dalam materi pembelajaran. yaitu (1) informasi verbal, (2) keterampilan intelektual, (3) strategi kognitif, (4) sikap, dan (5) keterampilan motorik. Strategi pengorganisasian materi pembelajaran terdiri dari tiga tahapan proses berpikir, yaitu (1) pembentukan konsep, (2) intepretasi konsep, dan (3) aplikasi prinsip. Strategi-strategi tersebut memegang peranan sangat penting dalam mendesain pembelajaran. Kegunaannya dapat membuat mahasiswa lebih tertarik dalam belajar, mahasiswa otomatis belajar bertolak dari prerequisites, dan dapat meningkatkan hasil belajar [9].

Menurut [10] mengatakan bahwa modul ialah suatu unit program belajar mengajar terkecil yang secara terperinci menggariskan : 1) tujuan instruksional yang akan dicapai, 2) topik yang akan dijadikan pangkal proses belajar-mengajar, 3) pokok-pokok materi yang akan dipelajari, 4) kedudukan dan fungsi modul dalam kesatuan program yang luas, 5) peran guru dalam proses belajar mengajar, 6) alat-alat dan sumber yang akna dipergunakan, 7) kegiatan-kegiatan belajar yang harus dilakukan dan dihayati murid secara berurutan, 8) lembar kerja yang harus diisi oleh anak, 9) program evaluasi yang kaan dilaksanakan.

4. Modul Ajar Elektronik

Perkembangan teknologi e-book mendorong terjadinya perpaduan antara teknologi cetak dengan teknologi komputer dalam kegiatan pembelajaran. berbagai media pembelajaran cetak, salah satunya modul dapat ditransformasikan penyajiannya ke dalam bentuk elektronik, sehingga melahirkan istilah modul elektronik atau yang dikenal dengan istilah $e$-modul. Istilah modul elektronik merupakan penggabungan istilah modul dalam bentuk bahan ajar elektronik (e-book). Menurut mendefinisikan modul elektronik sebagai sebuah bentuk penyajian bahan belajar mandiri yang disusun secra sistematis ke dalam unit pembelajaran terkecil untuk mencapai tujuan pembelajaran tertentu, yang disajikan dalam format elektronik.

Berdasarkan pengertian mengenai modul dan modul elektronik tersebut, terlihat bahwa tidak ada perbedaan prinsip pengembangan antara modul konvensional (cetak) dengan modul elektronik. Perbedaan hanya terdapat pada format penyajian secara fisik saja, sedangkan komponenkomponen penyusun modul tersebut tidak memiliki perbedaan. Modul elektronik mengadaptasi komponenkomponen yang terdapat dalam modul cetak pada umumnya. Perbedaan hanya pada penyajian fisik modul elektronik yang membutuhkan perangkat komputer untuk menggunakannya dan memerlukan aplikasi tambahan untuk menjalankan modul elektronik tersebut yang dikenal dengan e-book reader. Beberapa contoh aplikasi e-book reader antara lain Nook, Kobo, Kindle, Magic Scroll. Sebagian besar ponsel keluaran terbaru juga sudah mendukung penggunaan aplikasi e-book, sehingga bisa memudahkan pengguna dalam mempelajari suatu materi pelajaran.

5. CAI (Computer Assisted Intruction)

Pada awalnya penggunaan perangkat multimedia berbasis komputer ini dikenal dengan nama CAI (Computer Assisted Instruction) dan CMI (Computer 


\section{KคRMดPดTI}

Mânăgé fnstruction). Menurut [13]. secara luas CAI ialah penggunaan komputer secara langsung terhadap siswa untuk menyampaikan isi pelajaran, memberikan latihan-latihan dan menguji kemampuan belajar siswa. Karena keluwesan dan kemampuan suatu komputer untuk memberikan pembelajaran yang bervariasi, maka komputer dapat dianggap sebagai peranan seorang tutor yang "sabar" tanpa batas. Komputer dapat juga digunakan untuk mengontrol media lain dan memberikan siswa bahan referensi yang diperlukan, bantuan penampilan dan pelayanan administrasi dan mensimulasikan fasilitas lingkungan dan laboratorium.

CAI (Computer Assisted Instruction) dapat beragam bentuknya, ini bergantung pada kecakapan pengembang

Pemanfaatan komputer dalam pendidikan saat ini dikenal dengan pembelajaran den gan bantuan komputer (CAI). CAI (Computer Assisted Instruction) adalah suatu sistem penyampaian materi pelajaran yang berbasis mikroposesor yang pelajarannya dirancang dan diprogram ke dalam sistem tersebut. Dalam mode ini, computer bias menampilkan pembelajaran, men ggunakan berbagai jenis media (teks, gambar, suarA,video), menyediakan aktivitas dan suasana pembelajaran, kuis atau dengan menyediakan interaksi dari siswa, mengevaluasi jawaban siswa, menyediakan umpan balik dan menentukan aktivitas tindak lanjut yang sesuai sehingga siswa dapat berinteraksi secara aktif.

\section{Moodle}

Moodle merupakan salah satu aplikasi e-learning yang berbasis open source. Moodle adalah paket software yang diproduksi untuk kegiatan belajar berbasis internet dan web. Moodle pertama kali dikembangkan oleh Martin Dougiamas, dibantu oleh seorang desainer pedagogi instruksionis sosial. Moodle (Modular Object-Oriented Dynamic Learning Environment) adalah sebuah system pembelajaran elektronik jarak jauh berbasis digital. Program ini memungkinkan penggunanya untuk membuat berbagai macam modul yang dinamis dalam sebuah pengaturan pembelajaran seperti kelas, pelatihan, tutorial dan sebagainya, sehingga aplikasi ini disebut Modular. .

Moodle termasuk yang terbaik secara kelengkapan fitur jika dibandingkan dengan software LSM lainnya. Dalam proses customization pada Moodle relatif tidak merepotkan, meskipun tidak memahami bahasa pemrograman dengan baik. Template dan themes yang disediakan Moodle juga cukup banyak dan mendukung 40 bahasa termasuk bahasa Indonesia. Moodle memiliki fitur lesson yang tidak ada di LSM lain. Fitur lesson ini dapat mengarahkan siswa dan peserta e-learning diarahkan secara otomatis ke halaman lain sesuai dengan jawaban dari pertanyaan di suatu halaman.

\section{METODOLOGI}

\section{A. Jenis penelitian}

Penelitian ini merupakan jenis penelitian pengembangan atau research and development (R\&D). Metode pengembangan merupakan cara yang digunakan untuk menemukan, mengembangkan dan menguji suatu
Volume 8, Nomor 2, Tahun 2019

produk berdasarkan prosedur yang sistematis, sehingga produk yang dihasilkan memiliki nilai ilmiah yang tinggi dan dapat dipercaya. Produk yang dimaksud berupa modul elektronik dalam bentuk web yang digunakan sebagai media pembelajaran pemrograman grafik kelas XII. Jenis penelitian ini dipilih karena prosedur yang ada di dalamnya sangat tepat untuk melakukan penggembangan sebuah media yang mempunyai tujuan untuk mengembangkan dan memvalidasi produk.

Model pengembangan yang digunakan dalam penelitian ini yaitu model pengembangan ADDIE. ADDIE merupakan singkatan dari Analysis, Design, Development or production, Implementation or delivery and Evaluation. Model pengembangan ADDIE ini sering digunakan dalam penelitian atau pengembangan media atau bahan ajar seperti modul, LKS, e-learning, e-modul dan buku panduan. Langkah-langkah dalam model pengembangan ADDIE ini adalah sebagai berikut:

a. Analysis

Pada tahap pertama yaitu analisis, kegiatan utama yang dilakukan adalah menganalisis perlunya pengembangan e-modul pada mata pelajaran Pemrograman Grafik kelas XII Rekayasa Perangkat Lunak di SMK Negeri 2 Tabanan. Berdasarkan analisis dari permasalahan dan kebutuhan yang diperlukan oleh guru dan siswa, diperlukan adanya sebuah media pembelajaran melihat permasalahan tentang kurangnya media pembelajaran dan sumber ajar. Pengembangan $e$ modul sebagai media pembelajaran dirasa tepat untuk mengatasi permasalahan yang ditemui karena $e$-modul dinilai efektif dan efisien dalam mengembangakan kemampuan berfikir siswa. Peneliti juga menganalisis fasilitas penunjang pengembangan e-modul yang akan diterapkan sudah tersedia dan memadai. Fasilitas penunjang seperti PC (personal computer) di laboratorium komputer berjumlah 40 unit dan berfungsi dengan baik, jumlah tersebut sudah cukup untuk siswa yang berjumlah 24 orang. Berdasarkan wawancara yang dilakukan penulis dengan guru mata pelajaran dan Kaprog RPL didapatkan analisis sebagai berikut:

1. Analisis sumber belajar

Sumber belajar yang ada di SMK Negeri 2 Tabanan, khususnya di jurusan Rekayasa Perangkat Lunak pada mata pelajaran Pemrograman Grafik menggunakan powerpoint yang materinya diambil dari modul-modul perkuliahan yang didapatkan dari internet. Proses pembelajaran seperti belum dapat menunjang kebutuhan belajar siswa, karena materi yang di sediakan masih terbatas dan terkadang sulit disesuaikan dengan kompetensi dasar yang direncanakan.

2. Analisis mata pelajaran

Analisis mata pelajaran, pada tahap ini dilakukan analisis terhadap mata pelajaran pemrograman grafik kelas XII bidang keahlian RPL yaitu tujuan dari pembelajaran pemrograman grafik kelas XII sesuai dari silabus yang ada yaitu Memahami struktur pemrograman grafik; Memahami grafika komputer dan pemakainnya; Menyajikan hasil pengolahan grafika komputer; Memahami konsep dasar library grafik; Menyajikan komponen - komponen library grafik; Memahami 
ISSN 2252 - 9063

Kumpulan Artikel Mahasiswa Pendidikan Teknik Informatika

(KARMAPATI)

\section{KARMAPAT}

pembuatan primitive drawing; Menyajikan hasil primitive drawing; Memahami grafik 2 dimensi; Menciptakan grafik 2 dimensi; Menerapkan transformasi objek 2 dimensi; Menciptakan animasi 2 dimensi; Menerapkan pembuatan model objek 3 dimensi; Menciptakan model objek 3 dimensi; Memahami transformasi 3 dimensi; Menciptakan animasi 3 dimensi; Memahami konsep sudut pandang kamera dan proyeksi 3 dimensi; Mengolah proyeksi paralel, proyeksi, perspektif, pandangan stereo dan taksonomi proyeksi; Menerapkan efek morphing pada objek 2 dimensi dan 3 dimensi; Menciptakan efek morphing untuk objek; Memahami konsep fraktal untuk bentuk - bentuk fenomena alam; Menciptakan bentuk fenomena alam dengan konsep fraktal; Menerapkan rendering objek 3 dimensi; Menyajikan rendering objek 3 dimensi.

3. Analisi karakteristik siswa

Analisis karakteristik siswa. Berdasarkan hasil observasi yang dilakukan di dalam kelas. Karakteristik siswa lebih cenderung memiliki sikap yang kurang tanggap/aktif di kelas. Siswa cenderung menunggu penjelasan dari guru dan lebih banyak diam selama proses pembelajaran, begitu juga pada saat siswa diberikan kesempatan untuk menyampaikan pendapat, siswa kebanyakan diam dan menunggu guru memberikan petunjuk

\section{b. Design}

Dalam perancangan e-modul ini, peneliti terlebih dahulu merancang sebuah kerangka modul pembelajaran yang nantinya akan dirubah menjadi $e$-modul. Peneliti merancang konsep-konsep yang mendasari pengembangan e-modul pada mata pelajaran Pemrograman Grafik ini. Peneliti merancang konsep $e$ modul agar sesuai dengan analisis kebutuhan yang diperlukan.

Langkah selanjutnya adalah pengembangan kerangka e-modul mata pelajaran Pemrograman Grafik. Kerangka modul ini telah disesuaikan berdasarkan kebutuhan yang diperlukan. Berikut ini adalah kerangka e-modul yang akan dikembangkan.

c. Development

Tahap development (pengembangan) merupakan tahap ketiga dari model ADDIE. Pada tahap ini sudah mulai melaksanakan proses pembuatan e-module berdasarkan kerangka $e$-module yang telah di buat sebelumnya. Desain tersebut akan diimplementasikan ke dalam moodle.

\section{d. Implementation}

Pada tahap ini, dilakukan implementasi dari $e$-modul yang sudah dibuat. E-modul ini akan diimplementasikan pada mata pelajaran Pemrograman Grafik di kelas XII. Guru akan menggunakan media pembelajaran $e$-modul ini untuk mengajar di kelas. Sedangkan para siswa akan mengakses $e$-modul dari PC yang ada di laboraturium untuk proses pembelajaran. Guru akan mengelola kegiatan pembelajaran di kelas dengan menggunakan $e$ modul yang telah di kembangkan. Tahap ini rancangan yang telah dibuat diimplementasikan dengan menjalankan aplikasi sesuai dengan perangkat lunak dan perangkat keras.

\section{e. Evaluation}

Volume 8, Nomor 2, Tahun 2019

Setelah dilakukan implementasi pada $e$-modul yang dibuat, maka selanjutnya adalah melakukan evaluasi terhadap penggunaan e-modul ini dalam proses pembelajaran. Tahap evaluation merupakan tahap yang dilakukan untuk mengevaluasi proses pengembangan produk sesuai dengan model yang digunakan. Pada tahap ini hanya digunakan evaluasi formatif yang bertujuan untuk mengumpulkan data tentang efektivitas dan efisiensi media untuk mencapai tujuan yang ditetapkan.

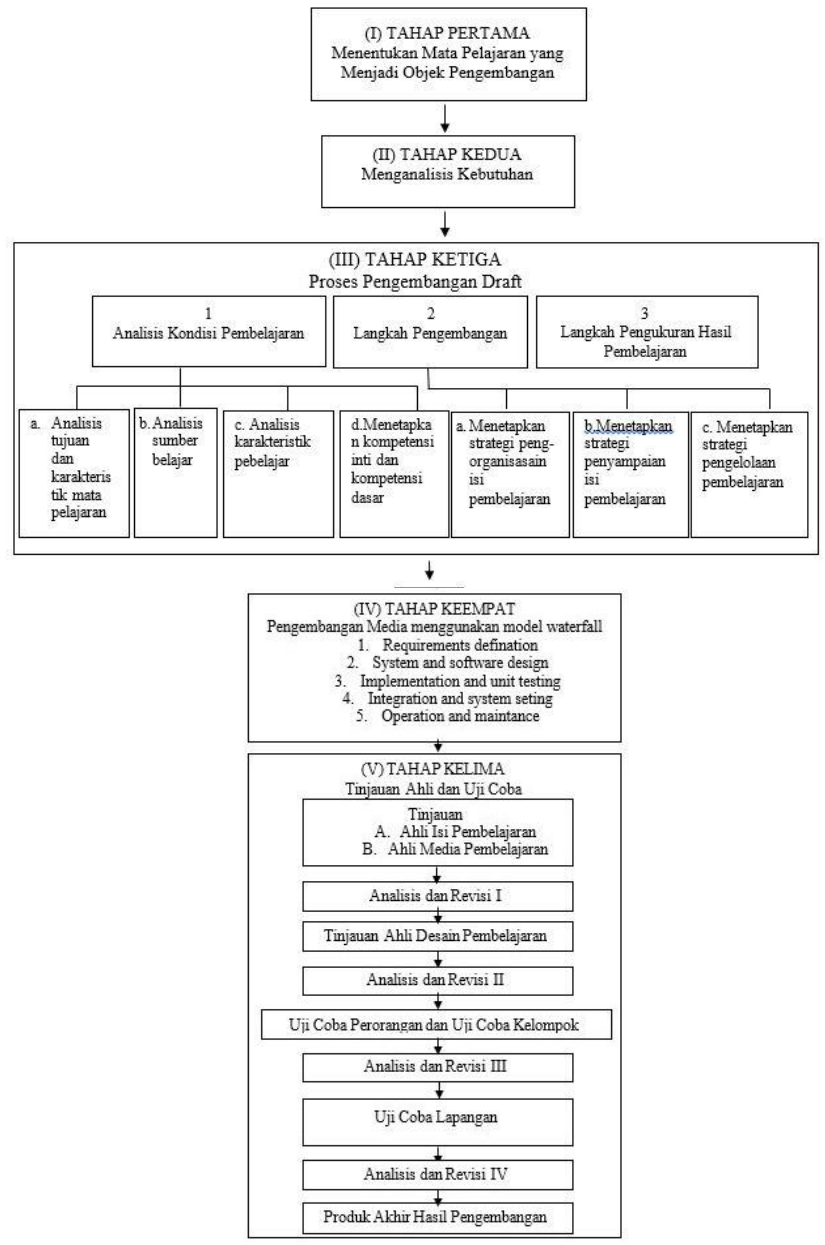

Gambar. 1. Tahap Pengembangan Desain Media

B. Instrumen Pengumpulan Data

Dalam penelitian ini digunakan instrumen berupa angket untuk mengumpulkan data yang dibutuhkan terkait informasi tentang sumber belajar, karakteristik siswa, uji kevalidan e-modul, serta uji respon guru dan siswa terhadap e-modul yang dikembangkan. Teknik pengumpulan data dapat dilihat pada Tabel 2 berikut.

TABEL 2. TEKNIK PENGUMPULAN DATA

\begin{tabular}{|l|l|l|l|}
\hline No & Jenis Data & Metode & Sumber data \\
\hline 1 & $\begin{array}{l}\text { Informasi tentang } \\
\text { sumber belajar }\end{array}$ & $\begin{array}{l}\text { Angket dan } \\
\text { wawancara }\end{array}$ & $\begin{array}{l}\text { Guru mata pelajaran } \\
\text { pemrograman grafik dan } \\
\text { peserta didik kelas XII }\end{array}$ \\
\hline
\end{tabular}


ISSN 2252 - 9063

Kumpulan Artikel Mahasiswa Pendidikan Teknik Informatika

(KARMAPATI)

KดRMดPดT

\begin{tabular}{|l|l|l|l|}
\hline No & Jenis Data & Metode & Sumber data \\
\hline 2 & $\begin{array}{l}\text { Karakteristik } \\
\text { siswa }\end{array}$ & $\begin{array}{l}\text { RPL di SMK Negeri 2 } \\
\text { Tabanan }\end{array}$ \\
\hline 3 & $\begin{array}{l}\text { Kevalidan E- Angket } \\
\text { modul }\end{array}$ & $\begin{array}{l}\text { Peserta didik kelas XII } \\
\text { RPL di SMK Negeri 2 } \\
\text { Tabanan }\end{array}$ \\
\hline 4 & $\begin{array}{l}\text { Respon guru dan } \\
\text { siswa }\end{array}$ & $\begin{array}{l}\text { Ahli Isi Pembelajaran, } \\
\text { Ahli Desain }\end{array}$ \\
\hline
\end{tabular}

D. Teknik Analisis dan Validasi Data

Pada kegiatan observasi guna mendapat informasi sumber belajar dan karakteristik pembelajar, digunakan jenis angket terbuka. Melalui metode angket ini peneliti mengetahui masalah yang terjadi ketika pembelajaran berlangsung terkait sumber belajar, materi, media, dan ketertarikan siswa dalam pembelajaran pemrograman grafik. Uraian singkat tentang teknis analisis data yang digunakan dalam penelitian ini adalah sebagai berikut.

1. Validasi data e-modul

Penilaian persentase hasil yang diperoleh menggunakan rumus sebagai berikut.

Persentase $=\frac{\text { Skor Perolehan }}{\text { Skor Maksimal }} x 100 \%$

Untuk melihat tingkat pencapaian pengembangan emodul berdasarkan perhitungan persentase maka ditetapkan kriteria sesuai Tabel 3 tentang tingkat pencapaian seperti terlihat pada tabel berikut.

TABEL 3. KONVERSI TINGKAT PENCAPAIAN DENGAN SKALA

Volume 8, Nomor 2, Tahun 2019

\begin{tabular}{|l|l|l|}
\hline $\begin{array}{l}\text { Tingkat } \\
\text { Pencapaian }\end{array}$ & Kualifikasi & Keterangan \\
\hline $90 \%-100 \%$ & Sangat baik & Tidak perlu direvisi \\
\hline $75 \%-89 \%$ & Baik & Tidak perlu direvisi \\
\hline $65 \%-74 \%$ & Cukup & Direvisi \\
\hline $55 \%-64 \%$ & Kurang & Direvisi \\
\hline $0 \%-54 \%$ & Sangat kurang & Direvisi \\
\hline
\end{tabular}

2. Analisis data respon guru dan siswa

Analisis data respon peserta didik dan guru dimaksudkan untuk mengetahui bagaimana respon peserta didik terhadap $e$-modul yang dikembangkan. Data respon peserta didik dan guru secara klaksikal dianalisis secara deskriptif. Analisis ini didasarkan pada rata - rata kelas $(\bar{x})$ dari respon peserta didik dan guru. Dalam melakukan perhitungan analisis data respon maka didasarkan pada rata-rata kelas $(\bar{x})$ dari respon peserta didik, Mi, dan SDi. Rata-rata kelas dari skor respon peserta didik dihitung dengan rumus.

$$
\bar{x}=\frac{\sum x}{N}
$$

Keterangan:

$\bar{x}=$ Rata - rata kelas untuk skor respon siswa

$\sum x=$ Jumlah skor respon siswa

$\mathrm{N}$ = Banyaknya siswa

Sedangkan untuk mencari mean ideal (Mi) dan standar deviasi ideal (SDi) digunakan rumus sebagai berikut:

$\mathrm{Mi}=\frac{1}{2}($ skor maksimal + skor terendah $)$

$\mathrm{SDi}=\frac{1}{6}($ skor tertinggi - skor terendah $)$

Rata-rata kelas $(\bar{x})$ dari skor respon kemudian dikategorikan dengan menggunakan pedoman pada Tabel 4 konversi rata-rata kelas untuk dapat mengetahui kategori hasil respon siswa dan guru.

Tabel 4. KONVERSI RATA-RATA KELAS

\begin{tabular}{|l|l|l|}
\hline No & Interval & Kategori \\
\hline 1 & $\mathrm{Mi}+1,5 \mathrm{SDi} \leq \overline{\boldsymbol{x}}$ & Sangat Positif \\
\hline 2 & $\mathrm{Mi}+0,5 \mathrm{SDi} \leq \overline{\boldsymbol{x}}<\mathrm{Mi}+1,5 \mathrm{SDi}$ & Positif \\
\hline 3 & $\mathrm{Mi}-0,5 \mathrm{SDi} \leq \overline{\boldsymbol{x}}<\mathrm{Mi}+0,5 \mathrm{SDi}$ & Kurang Positif \\
\hline 4 & $\mathrm{Mi}-1,5 \mathrm{SDi} \leq \overline{\boldsymbol{x}}<\mathrm{Mi}-1,5 \mathrm{SDi}$ & Negatif \\
\hline 5 & $\bar{x}<\mathrm{Mi}-1,5 \mathrm{SDi}$ & Sangat Negatif \\
\hline
\end{tabular}

\section{PEMBAHASAN}

Pengembangan $e$-modul pada mata pelajaran pemrograman grafik kelas XII memiliki tujuan untuk membantu siswa dalam menjalani proses pembelajaran di dalam kelas. Dari hasil analisis sumber belajar yang dilakukan, siswa belum menggunakan $e$-modul dalam proses belajar dan hanya bersumber kepada internet. Dengan demikian pengembangan $e$-modul pemrograman grafik sangat diperlukan khususnya pada Program 


\section{KARMAPดT}

Keâhtrân Rekayasa Perangkat Lunak kelas XII di SMK Negeri 2 Tabanan.

Selain itu, e-modul ini dikembangkan dengan menggunakan model pembelajaran Project Based Learning dengan tujuan agar tahapan - tahapan pembelajaran yang ada didalam e-modul ini dapat terstruktur dan terarah. Pembahasan difokuskan pada penyajian dan analisis data serta revisi yang dilakukan terhadap objek pengembangan. Tahap pertama menentukan mata pelajaran yang menjadi objek penelitian yaitu mata pelajaran pemrograman grafik. Tahap kedua yaitu menganalisis kebutuhan dari mata pelajaran pemrograman grafik. Tahap ketiga adalah proses pengembangan draft, yaitu (a) analisis kondisi pembelajaran, (b) langkah pengembangan. Tahap keempat pengembangan media menggunakan model waterfall, yang meliputi (1) Requirements Analysis and Definition, (2) System and Software Design, (3) Implementation and Unit Testing, (4) Integration and System Testing, dan (5) Operation and Maintenance.

Ada pun kendala-kendala yang di hadapi oleh peneliti diantaranya: (1) Jarak yang sangat jauh dari sekolah tempat penelitian, (2) susahnya mencari materi pelajaran untuk mata pelajaran pemrograman grafik , (3) Saat melaksanankan pengujian lapangan sekolah libur, hal ini menyebabkan terlambatnya penelitian. Saran untuk peneliti selanjutnya agar lebih memperhatikan dan menyususn dengan baik jadwal penelitian agar penelitian yang kita lakukan tersetruktur dan tepat waktu.

E-modul pemrograman grafik yang dikembangkan menggunakan metode Cai dimana Proses pembelajaran dengan menggunakan Media CAI merupakan pembelajaran yang memanfaatkan komputer sebagai pembantu atau tambahan dalam belajar, pemanfaatannya meliputi penyajian informasi isi materi pelajaran, latihan, atau kedua-duanya. Media pembelajaran CAI memungkinkan dalam penyajian tutorial serta Drill and Practice untuk mempermudah pemahaman siswa dalam belajar. Adapun gambaran skema pembelajaran e-modul berbasis model pembelajaran project based learnigng dengan menggunakan CAI dapat dilihat pada Gambar 2 tentang skema pengembangan e-modul menggunakan CAI dimana terdapat 4 obeject yaitu guru, e-modul, siswa, dan admin, dan hasil dari pengembangan e-modul project based learning dapat dilihat pada Gambar 2 .

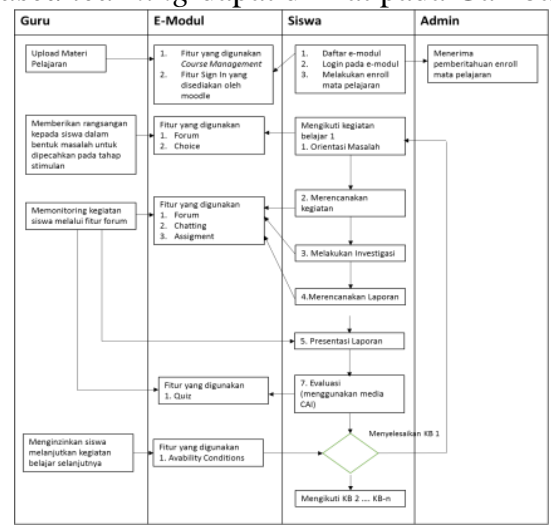

Volume 8, Nomor 2, Tahun 2019

Gambar. 2. Skema pengembangan e-modul project based learning menggunakan pendekatan CAI

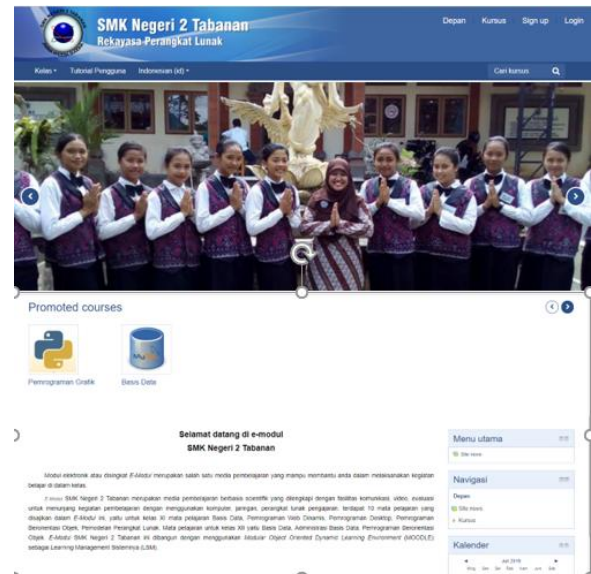

Gambar. 3. Halaman Utama E-Modul

Pengguna yang dapat menggunakan semua fitur yang ada dalam e-modul dengan model Project Based Learning ini adalah pengguna yang sudah terdaftar pada e-modul ini.

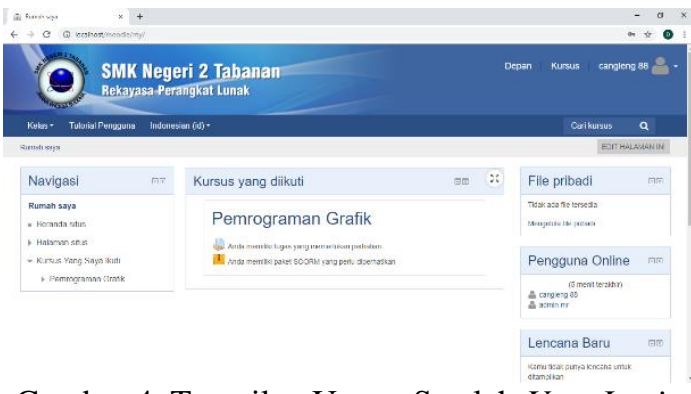

Gambar 4. Tampilan Utama Setelah User Login

Dalam e-modul Pemrograman Grafik dengan menggunakan model project based learning terdapat dua pengguna yaitu guru, dan siswa.

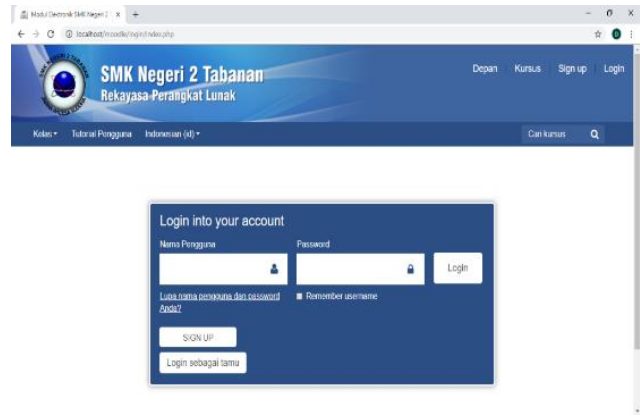

Gambar 5. Halaman Login 


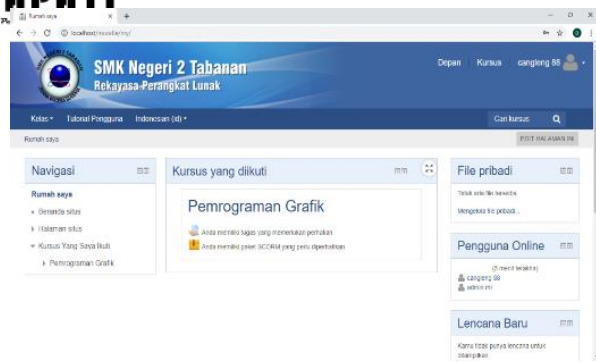

Gambar 6. Halaman Pengguna

Setelah siswa berhasil melakukan login maka muncul halaman mata pelajaran yang telah diikuti oleh siswa di $e$-modul

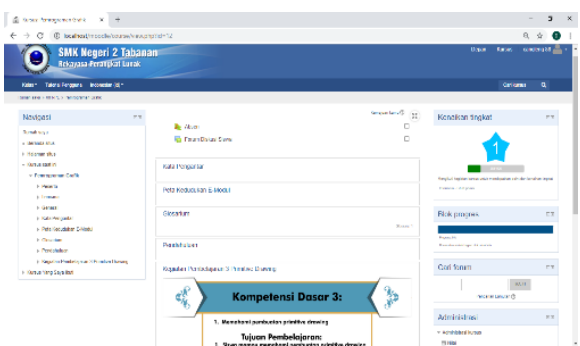

Gambar 7. Hasil Pengembangan Halaman Kegiatan Pembelajaran

Halaman kegiatan belajar menampilkan kegiatan pembelajaran 1 sampai kegiatan pembelajaran 8. Setiap kegiatan pembelajaran menggunakan model pembelajaran Project Based Learning dimana dalam tahapannya terdapat orientasi masalah, menyusun rencana proyek, melakukan investigasi, merencanakan laporan, presentasi laporan, dan evaluasi.

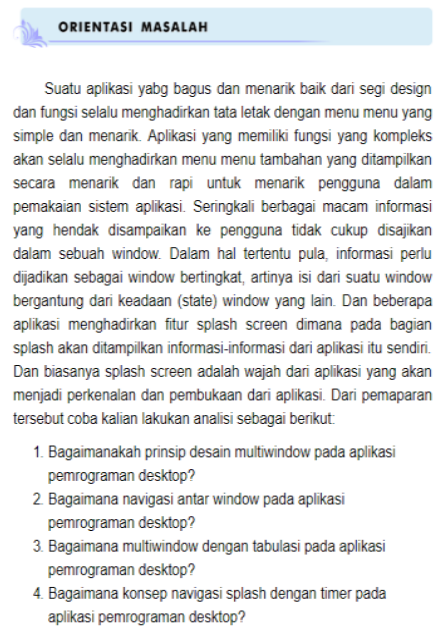

Gambar 8. Halaman Tahap Orientasi Masalah

Pada tahap orientasi masalah di setiap kegiatan pembelajaran merupakan tahap yang berisi tentang pengenalan, pendahuluan dari materi kegiatan pembelajaran yang akan di pelajari oleh siswa.

\section{MENYUSUN RENCANA PROYE}

Berikut merupakan ketentuan dari pengerjaan project kegiatan pembelajaran 3

@ Group Proyek 3

Pilih kelompok untuk melakukan kegiatan penugasan proyek kerja pada kegiatan pembelajaran 3

Ketentuan Proyek

Baca dan cermati bersama kelompok kalian mengenai ketentuan dan pembuatan penugasan proyek pada kegiatan pembelajaran 3

Gambar 9. Tahapan Menyusun Rencana Proyek

Tahap menyusun rencana proyek di setiap kegiatan pembelajaran merupakan tahap yang berisi tentang proyek yang akan dikerjakan beserta ketentuan pengerjaan.

\begin{tabular}{|c|c|c|c|}
\hline \multicolumn{4}{|c|}{ Your selection: Proyek 3 B } \\
\hline Pilihan & $\begin{array}{l}\text { Grup } \\
\text { Show descriptions }\end{array}$ & $\begin{array}{l}\text { Anggota / } \\
\text { Kapasitas }\end{array}$ & $\begin{array}{l}\text { Group members } \\
\text { Tampilkan }\end{array}$ \\
\hline & Proyek 3 A & $1 / 4$ & \\
\hline • & Proyek 3 B & $1 / 4$ & \\
\hline & Proyek 3 C & $0 / 4$ & \\
\hline & Proyek 3D & $0 / 4$ & \\
\hline 0 & Proyek $3 \mathrm{E}$ & $0 / 4$ & \\
\hline & Proyek $3 \mathrm{~F}$ & $0 / 4$ & \\
\hline
\end{tabular}

Gambar 10. Halaman Tahapan Menyusun Rencana Proyek

Fitur yang digunakan pada tahap menyusun rencana proyek yaitu fitur group choice dan page.

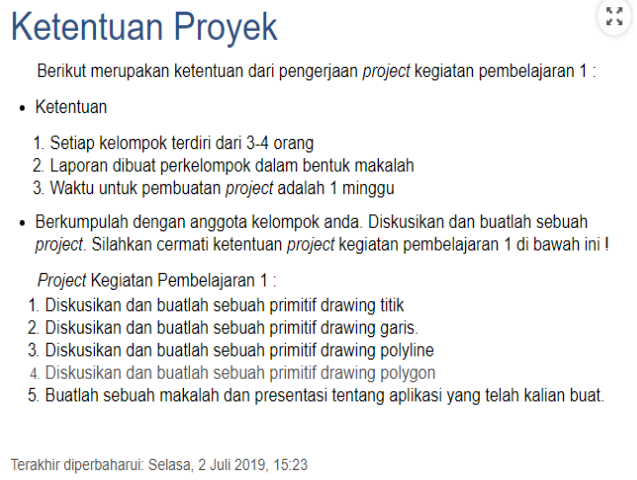

Gambar 11. Tampilan Fitur Page pada Tahap Menyusun Rencana Proyek

Ketika fitur page Ketentuan Pengerjaan Project 1 di klik, maka akan muncul tampilan seperti pada Gambar11. 
ISSN 2252 - 9063

Kumpulan Artikel Mahasiswa Pendidikan Teknik Informatika

(KARMAPATI)

KดRMAPคTI

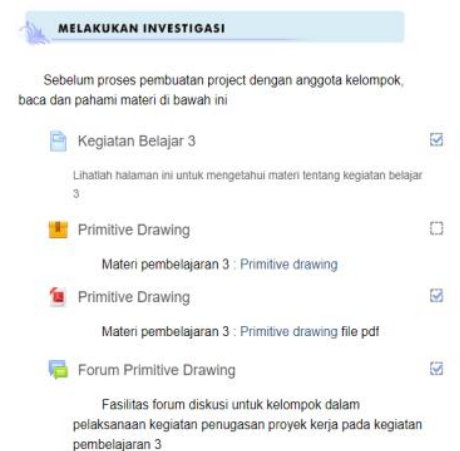

Gambar 12. Hasil Pengembangan Halaman Melakukan Investigasi

Fitur yang terdapat pada tahap melakukan investigasi yaitu fitur SCORM, File, Forum. Ketika fitur SCORM di klik, siswa dapat menampilkan materi secara langsung di $e$-modul sama halnya seperti slide show dapat dilihat pada Gambar12.

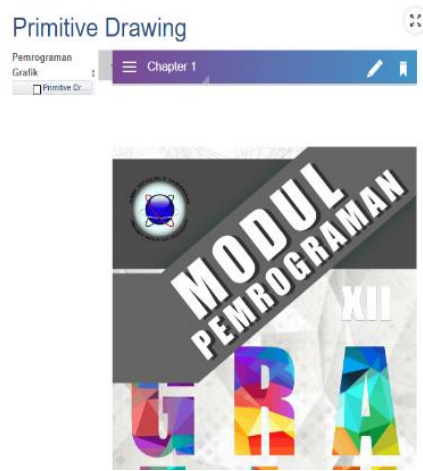

Gambar 13. Tampilan Fitur SCORM pada Tahap Melakukan Investigasi

Selanjutnya fitur yang ada yaitu fitur file. Fitur file lebih digunakan untuk siswa melakukan download materi yang nantinya dapat dibuka di rumah.

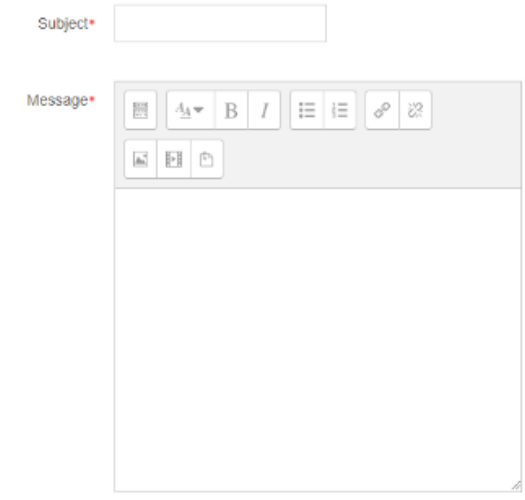

Gambar 14. Tampilan fitur Forum pada Tahap Melakukan Investigasi

Setelah pengembangan mendia selesai dilakukan menuju tahap terakhir yaitu, Tahap Kelima adalah tahap terakhir dalam pengembangan e-modul pemrograman grafik yaitu tinjauan ahli dan uji coba $e$ - modul. E-modul yang dibuat diujicobakan terlebih dahulu ke dosen ahli
Volume 8, Nomor 2, Tahun 2019

serta guru ahli, dimana dilakukan 3 pengujian yaitu uji ahli design, uji ahli isi, dan uji ahli media. Setelah melakukan pengujian terhadap ahli kemudian e-modul akan diimplementasikan di sekolah SMK Negeri 2 Tabanan.

Hasil penilaian ahli isi berdasarkan angket sudah dinyatakan sesuai, hal tersebut mengindikasi materi yang ada di dalam e-modul layak untuk digunakan dalam pembelajaran pemrograman grafik. Beberapa masukan dari ahli isi antara lain penambahan materi dan contoh soal latihan pembelajaran. Hasil penilaian dari ahli media adalah perhatikan Bahasa, perubahan model absensi, dan revisi model form. Kemudian tambahkan fitur-fitur terbaru. Ahli media juga menyarankan untuk menyesuaikan tampilan layout dan fitur SCROM.

Setelah dilakukannya tahap uji oleh ahli, selanjutnya dilakukan uji perorangan dengan pengambilan 3 sampel (siswa). Dari hasil perhitungan uji perorangan di dapat tidak ada siswa yang memberikan tanggapan sangat baik, 3 siswa dengan perolehan $100 \%$ memberikan tanggapan baik dan tidak ada siswa yang memberikan tanggapan cukup, kurang maupun sangat kurang seperti yang dapat dilihat pda Tabel 5.

TABEL 5. REKAPILTULASI PENILAIAN PADA UJI COBA PERORANGAN

\begin{tabular}{|l|c|c|}
\hline \multicolumn{1}{|c|}{$\begin{array}{c}\text { Konversi tingkat } \\
\text { pencapaian }\end{array}$} & Persentase (\%) & Jumlah Responden (orang) \\
\hline Sangat Baik & $0 \%$ & 0 \\
\hline Baik & $100 \%$ & 3 \\
\hline Cukup & $0 \%$ & 0 \\
\hline Kurang & $0 \%$ & 0 \\
\hline Sangat Kurang & $0 \%$ & 0 \\
\hline
\end{tabular}

Setelah uji perorangan selesai, dilakukan tahap uji kelompok kecil dengan menggunakan 12 orang siswa. Dari hasil perhitungan, didapat tidak ada responden yang memberikan tanggapan sangat baik, 12 responden dengan perolehan $100 \%$ siswa memberikan tanggapan baik dan tidak ada yang memberikan tanggapan cukup, kurang dan sangat kurang seperti yang dapat dilihat pada Tabel 6 .

TABEL 6. REKAPILTULASI PENILAIAN PADA UJI COBA KELOMPOK KECIL

\begin{tabular}{|l|c|c|}
\hline $\begin{array}{c}\text { Konversi tingkat } \\
\text { pencapaian }\end{array}$ & Persentase (\%) & $\begin{array}{c}\text { Jumlah Responden } \\
\text { (orang) }\end{array}$ \\
\hline Sangat Baik & $0 \%$ & 0 \\
\hline Baik & $100 \%$ & 12 \\
\hline Cukup & $0 \%$ & 0 \\
\hline Kurang & $0 \%$ & 0 \\
\hline Sangat Kurang & $0 \%$ & 0 \\
\hline
\end{tabular}

Kemudian dilakukan uji lapangan dengan menggunakan 19 orang siswa. Dari hasil perhitungan, 


\section{KคRMดPดT}

dídaptat 8 -résponden dengan perolehan $42.11 \%$ siswa memberikan tanggapan sangat baik, 11 responden dengan perolehan $57.89 \%$ siswa memberikan tanggapan baik dan tidak ada yang memberikan tanggapan cukup, kurang dan sangat kurang seperti yang dapat dilihat pada Tabel 7 .

TABEL 7. REKAPILTULASI PENILAIAN PADA UJI COBA KELOMPOK KECIL

\begin{tabular}{|l|c|c|}
\hline $\begin{array}{c}\text { Konversi tingkat } \\
\text { pencapaian }\end{array}$ & Persentase (\%) & $\begin{array}{c}\text { Jumlah Responden } \\
\text { (orang) }\end{array}$ \\
\hline Sangat Baik & $42.11 \%$ & 8 \\
\hline Baik & $57.89 \%$ & 11 \\
\hline Cukup & $0 \%$ & 0 \\
\hline Kurang & $0 \%$ & 0 \\
\hline Sangat Kurang & $0 \%$ & 0 \\
\hline
\end{tabular}

Setelah melakukan uji perorangan, kelompok kecil, dan lapangan dilakukannya pengambilan respon siswa dan guru. Dimana hasil yang didapat 7 orang siswa menjawab sangat baik dan 12 orang siswa menjawab baik sehingga diperoleh hasil presentase tingkat pencapaian respon siswa terhadap e-modul adalah $87.58 \%$ yang jika dikonversi akan masuk pada kualifikasi baik dengan sedikit revisi sedangkan untuk respon guru mendapatkan tingkat pencapaian sebesar $94 \%$ yang masuk dalam kualifikasi sangat baik seperti yang dapat dilihat pada Tabel 8 dan Gambar 15 yang menggambarkan tentang grafik hasil rekapitulasi respon siswa.

TABEL 8. REKAPILTULASI PENILAIAN PADA UJI RESPON SISWA

\begin{tabular}{|l|c|c|}
$\begin{array}{c}\text { Konversi tingkat } \\
\text { pencapaian }\end{array}$ & Persentase (\%) & $\begin{array}{c}\text { Jumlah Responden } \\
\text { (orang) }\end{array}$ \\
\hline Sangat Baik & $36.84 \%$ & 7 \\
\hline Baik & $63.16 \%$ & 12 \\
\hline Cukup & $0 \%$ & 0 \\
\hline Kurang & $0 \%$ & 0 \\
\hline Sangat Kurang & $0 \%$ & 0 \\
\hline
\end{tabular}

\section{Grafik Rekapitulasi Respon Siswa}

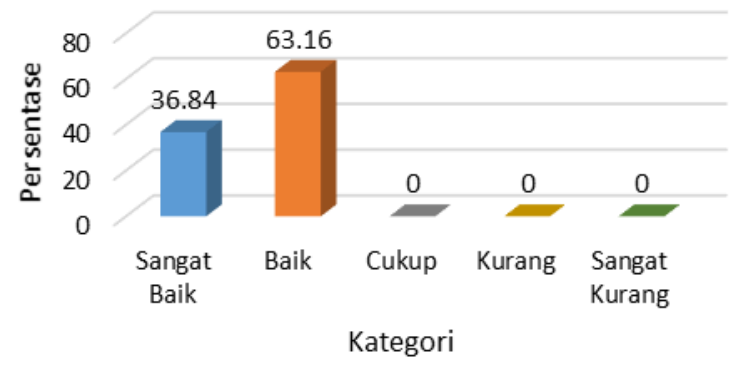

Gambar. 15 Grafik Hasil Rekapitulasi Respon Siswa

Berdasarkan hasil uji yang dilakukan, dapat disimpulkan pengembangan e-modul mata pelajaran pemrograman grafik yang telah dibuat menunjukan
Volume 8, Nomor 2, Tahun 2019

adanya keberhasilan, dan hal ini terbukti dengan pernyataan siswa yaitu siswa tertarik menggunakan $e$ modul dalam pelajaran pemrograman grafik dikarenakan e-modul berisikan materi yang jelas (respon siswa) sehingga sudah tersedianya sumber belajar.

Selama pelaksanaan penelitian, didapat beberapa kendala saat pengujian e-modul antara lain, Sulitnya mendapat literature yang sesuai untuk materi yang akan dimasukkan kedalam e-modul, dan pada saat uji coba ialah adanya gangguan jaringan antar komputer yang menyebabkan koneksi dari server ke client terputus. Solusi dari kendala tersebut ialah melakukan penelitian buku untuk materi yang akan digunakan. Literature juga menggunakan materi yang digunakan oleh guru dan mengambil literature dari perpustakaan Undiksha, lalu untuk kendala saat pengujian solusinya yaitu dengan memastikan jaringan dalam keadaan baik maka perlu dilakukan pengecekan ulang kabel LAN yang terpasang di setiap komputer.

\section{SIMPULAN \& SARAN}

Pengembangan $e$-modul pada mata pelajaran Pemrograman Grafik kelas XI memiliki tujuan untuk membantu siswa dalam menjalani proses pembelajaran di dalam kelas. Dari hasil analisis sumber belajar yang dilakukan, siswa belum menggunakan e-modul dalam proses belajar dan hanya bersumber kepada internet. Tahap kedua yaitu menganalisis kebutuhan dari mata pelajaran Pemrograman Grafik. Tahap ketiga adalah proses pengembangan draft, yaitu (a) analisis kondisi pembelajaran, (b) langkah pengembangan. Tahap keempat pengembangan media menggunakan model waterfall yang meliputi (1) Requirements defination, (2) System and software design, (3) Implementation and unit testing, (4) Integration and system testing dan (5) Operation and maintenance. Tahap Kelima adalah tahap terakhir dalam pengembangan e-modul pemrograman grafik yaitu pemakaian dan perawatan $e$ - modul.

Untuk mengetahui respon siswa terhadap pengembangan e-modul dilakukan uji perorangan dengan pengambilan 3 sampel (siswa). Dari hasil perhitungan uji perorangan di dapat tidak ada siswa yang memberikan tanggapan sangat baik,3 siswa dengan perolehan $100 \%$ memberikan tanggapan. Setelah uji perorangan selesai, dilakukan tahap uji kelompok kecil dengan menggunakan 12 responden dengan perolehan $100 \%$ siswa memberikan tanggapan baik. Kemudian dilakukan uji lapangan dengan menggunakan 19 orang siswa. Dari hasil perhitungan, didapat 8 responden dengan perolehan $42,11 \%$ siswa memberikan tanggapan sangat baik, 11 responden dengan perolehan $57,89 \%$ siswa memberikan tanggapan baik. Setelah melakukan uji perorangan, kelompok kecil, dan lapangan dilakukannya pengambilan respon siswa dan guru. Dimana hasil dari respon siswa yaitu sebanyak 7 siswa memberikan respon sangat baik, dan 12 siswa memberikan respon baik. Sedangkan untuk guru 100\% merespon sangat baik dan presentase tingkat pencapaian terhadap e-modul sebesar $87.58 \%$. Berdasarkan hasil uji yang dilakukan, dapat disimpulkan pengembangan $e$ - 


\section{KคRMดคดT}

modut mata "petajaran pemrograman grafik yang telah dibuat menunjukan adanya keberhasilan, dan hal ini terbukti dengan pernyataan siswa yaitu siswa tertarik menggunakan $e$-modul dalam pelajaran pemrograman grafik dikarenakan $e$-modul berisikan materi yang jelas (respon siswa) sehingga sudah tersedianya sumber belajar. Dengan demikian e-modul mata pelajaran pemrograman grafik dengan model pembelajaran Project Based Learning berhasil dikembangkan dengan valid.

Berdasarkan pengamatan penulis di lapangan, terdapat beberapa hal yang dapat dijadikan bahan pertimbangan untuk ditindak lanjuti, yaitu (1) Penggunaan e-modul sebagai sumber belajar pemrograman grafik diharapkan agar dapat memanfaatkan produk pembelajaran ini selama materi yang disajikan didalamnya masih relevan. (2) Produk e-modul Pemrograman Grafik dengan model Project Based Learning di SMK Negeri 2 Tabanan yang dikembangkan belum sampai pada tahap pengukuran hasil belajar akhir iswa dengan $e$-modul. Oleh karena itu, terbuka bagi para peneliti lain untuk mengkaji lebih jauh pengukuran hasil belajar akhir siswa menggunakan $e$ modul ini. (3) Aplikasi moodle harus dibuat dalam bentuk aplikasi instalasi sehingga pada saat penginstalan moodle pada tempat yang berbeda tidak membutuhkan waktu yang lama.

\section{REFERENS}

[1] Undang-Undang Dasar 1945 pasal 31 Ayat 1, Republik Indonesia, Jakarta.

[2] Undang-Undang No. 20 Tahun 2003 tentang Sistem Pendidikan Nasional

[3] Hujair AH.,Sanaky. 2009. Media Pembelajaran. Yogyakarta: Safiria Insania Press.

[4] Trianto. 2010. Mendesain Model Pembelajaran Inovatif- Progresif. Jakarta : Kencana.

[5] Mulyanto, Aunur R. 2008. Rekayasa Perangkat Lunak Jilid 2 untuk SMK. Jakarta : Direktorat Pembinaan Sekolah Menengah Kejuruan, Direktorat Jenderal Manajemen Pendidikan Dasar dan Menengah, Departemen Pendidikan Nasional.

[6] Santyasa, I.W. 2007. "Model-Model Pembelajaran Inovatif". Makalah Disajikan dalam Pelatihan tentang Penelitian Tindakan Kelas bagi Guru-Guru SMP dan SMA di Nusa Penida tanggal 29 Juni s.d 1 Juli 2007, Singaraja : Undiksha.

[7] Santyasa dan Sukadi. 2007. "Model-Model Pembelajaran Inofatif". Makalah disajikan dalam Pelatihan Setifikasi Guru Bagi Para Guru SD dan SMP di Provinsi Bali tanggal 26-30 Desember 2007, Singaraja : Undiksha.

[8] Winkel. 2009. Psikologi Pengajaran. Yogyakarta : Media A.

[9] Santyasa, I.W. 2009. "Metode Penelitian Pengembangan dan Teori Pengembangan Modul". Makalah Disajikan dalam Pelatihan Bagi Para Guru TK, SMP, SMA, dan SMK
Volume 8, Nomor 2, Tahun 2019

tanggal 12-14 Januari di Kecamatan Nusa Penida Kabupaten Klungkung, Singaraja : Undiksha.

[10] Andi Prastowo. (2011). Panduan Kreatif Membuat Bahan Ajar Inovatif. Yogyakarta: Diva Press. 